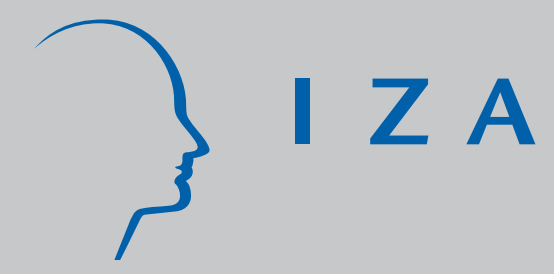

IZADP No. 2186

The Economics of College Sports:

Cartel Behavior vs. Amateurism

Lawrence M. Kahn

J une 2006 


\title{
The Economics of College Sports: Cartel Behavior vs. Amateurism
}

\author{
Lawrence M. Kahn \\ Cornell University, CESifo \\ and IZA Bonn
}

\author{
Discussion Paper No. 2186 \\ June 2006
}

\author{
IZA \\ P.O. Box 7240 \\ 53072 Bonn \\ Germany \\ Phone: +49-228-3894-0 \\ Fax: +49-228-3894-180 \\ Email: iza@iza.org
}

\begin{abstract}
Any opinions expressed here are those of the author(s) and not those of the institute. Research disseminated by IZA may include views on policy, but the institute itself takes no institutional policy positions.

The Institute for the Study of Labor (IZA) in Bonn is a local and virtual international research center and a place of communication between science, politics and business. IZA is an independent nonprofit company supported by Deutsche Post World Net. The center is associated with the University of Bonn and offers a stimulating research environment through its research networks, research support, and visitors and doctoral programs. IZA engages in (i) original and internationally competitive research in all fields of labor economics, (ii) development of policy concepts, and (iii) dissemination of research results and concepts to the interested public.
\end{abstract}

IZA Discussion Papers often represent preliminary work and are circulated to encourage discussion. Citation of such a paper should account for its provisional character. A revised version may be available directly from the author. 


\section{ABSTRACT}

\section{The Economics of College Sports: Cartel Behavior vs. Amateurism*}

This paper studies intercollegiate athletics in the context of the theory of cartels. Some point to explicit attempts by the National Collegiate Athletic Association (NCAA) to restrict output and payments for factors of production as evidence of cartel behavior. Others argue that such limits enhance product quality by preserving amateurism. I find that the NCAA's compensation limits on athletes lead to high levels of rents from the entertainment revenues produced by the athletes. The athletes producing these rents are disproportionately AfricanAmerican, while the beneficiaries are primarily white. The rents are typically spent on coaches' salaries, facilities, and nonrevenue sports. Although athletic departments considered as businesses lose money on average, there is some evidence, although not unanimous, that they generate alumni contributions, state appropriations, and additional student applications.

JEL Classification: L12, L44, I21

Keywords: cartel, monopsony, college athletics

Corresponding author:

Lawrence M. Kahn

264 Ives Hall

Cornell University

Ithaca, NY 14853

USA

E-mail: Imk12@cornell.edu

\footnotetext{
* The author thanks Charles Clotfelter for helpful comments and suggestions. Portions of this paper were written while the author was a Visiting Fellow in the Economics Department at Princeton University, supported by the Industrial Relations Section. He is very grateful for this support.
} 


\section{Introduction}

College sports generate pro-level revenues. Tables 1 and 2 compare ticket and television revenues for the two major revenue-producing college sports_-football and men's basketball—with the four major league professional men's team sports in North America. Table 1 shows that only the National Basketball Association (NBA) had higher ticket revenue than the sum of college football's and basketball's. In addition, adding television revenues for the annual National Collegiate Athletic Association (NCAA) men’s basketball tournament and available figures for several college football conferences as shown in Table 2, these totaled $\$ 675$ million per year, a larger figure than baseball or hockey. ${ }^{1}$

Most economists who have studied the NCAA view it as a cartel that attempts to produce rents by restricting output and limiting payments for inputs such as player compensation. Others, however, argue that NCAA rules enhance the value of amateur sports and preserve competitive balance. Moreover, they question the ability of a 1000plus school organization to effectively police its members which individually may be tempted to violate cartel rules (McKenzie and Sullivan 1987). In addition, even if the NCAA is an effective cartel, since athletic success depends in part on relative performance, curbing competition for inputs could be socially efficient (Frank 2004). For example, no matter how much schools spend on their basketball programs, only four will go to the Final Four.

Intercollegiate athletics is a most self-regulated enterprise, with the NCAA providing a vast set of rules governing the behavior of colleges and universities, supplemented of course by anti-trust and anti-discrimination law enforcement. The move toward self-regulation of intercollegiate athletics began in the nineteenth century over

\footnotetext{
1 Of course, Table 2 understates college sports' television revenues by not including (due to lack of data) several conferences such as the Big-10 and the Southeast Conference, as well as not including Bowl Game revenues or regular season college basketball revenue. However, it also understates professional sports revenue since it doesn't account for local media contracts.
} 
two issues arising from football. ${ }^{2}$ First, different schools used different rules regarding, for example, the number of players on the field. In addition, college teams regularly hired professionals to participate, in violation of the principle of amateurism in which the schools presumably believed. Second, unregulated football caused many serious injuries and some deaths among players. ${ }^{3}$ These issues prompted the birth of several facultycontrolled organizations representing colleges and universities in the late $19^{\text {th }}$ and early $20^{\text {th }}$ centuries, culminating in the 1905 formation of the Intercollegiate Athletic Association of the United States. This group renamed itself the NCAA in 1910 (Fleisher, Goff and Tollison, 1992, p.39), required the players to be amateurs and promulgated uniform playing rules that restricted violent play.

As of the early $20^{\text {th }}$ century, then, the organizational structure was in place to potentially support cartel-behavior. In this paper, I discuss evidence on whether the NCAA indeed has exercised cartel power and, more generally, whether college sports have generated rents that have directly benefited other units within colleges and universities. Moreover, I review evidence on the indirect effects of college sports on the rest of the university, including their effects on the quality and quantity of student applications, alumni contributions, and state appropriations for higher education.

\section{The NCAA as a Cartel}

Between 1920 and 1950, college football became much more popular and grew into a national sport. As revenues rose, schools had increasing incentives to recruit top athletes, and numerous instances of payments to athletes were observed in the 1940s (Zimbalist, 1999, p.9). To curb these payments, the NCAA in 1948 adopted the "Sanity Code,” which limited financial aid for athletes to tuition and fees, and required that aid

\footnotetext{
2 This description of the NCAA is based on Fleisher, Goff and Tollison (1992) and Zimbalist (1999).

3 For example, in 1905, 18 college football players died due to playing injuries (Fleisher, Goff and Tollison 1992, pp. 38-39).
} 
not be given solely on the basis of athletic ability. Rather, schools had to consider financial need. However, several schools refused to go along with the Sanity Code, and a number of southern conferences in 1949 were considering bolting from the NCAA (Sack and Staurowsky, 1998, p. 45). The lack of support for the Code led the NCAA in the early 1950s to amend its rules and allow athletes to receive scholarships based on their athletic ability, and schools were allowed to give awards that covered tuition and fees, as well as a living stipend. Perhaps more importantly, the NCAA set up an enforcement mechanism empowered to punish schools that violated its rules.

As college sports revenues have grown, so has the NCAA. In 1950, there were 387 member institutions, while by 2006, there are 1024 active member schools. ${ }^{4}$ In 1973, the NCAA created three divisions (I, II and III, for which the membership rules are described in the Appendix), and in recent years, the organization has further segmented Division I into IA (the truly big time athletic schools), I-AA and I-AAA, lesser programs within this class. This segmentation is viewed by some (e.g. Fleisher, Goff and Tollison 1992) as an attempt by the larger schools to protect their rents from being lost to the smaller schools.

According to the cartel theory of the NCAA, the organization has restricted output, defeated rival groups, and enforced collusive restrictions on payments for factors of production, including player compensation, recruiting expenses, and assistant coaches’ salaries (Fleisher, Goff and Tollison 1992; Zimbalist 1999). In this view, these activities of the NCAA lead to the usual consumer and worker welfare losses associated with monopoly and monopsony. In addition, the exercise of monopsony power is said to cause a redistribution of wealth from revenue-producing athletes to coaches and athletes in non-revenue-producing sports. Since the revenue-producing athletes are disproportionately nonwhite and of lower family income than coaches or non-revenue-

\footnotetext{
${ }^{4}$ See Fleisher, Goff and Tollison (1992), p. 67 and NCAA web site, http://www.ncaa.org , accessed February 15, 2006.
} 
producing athletes, this is viewed by some as a regressive outcome relative to a competitive market. $^{5}$

On the other hand, some have argued that NCAA rules on player compensation enhance the economic value produced by the college sports enterprise, since part of the appeal of college sports is the spirit of amateurism, in contrast to the cold professionalism of major league sports (McKenzie and Sullivan 1987). It is theoretically possible for the demand for amateur college sports to be much higher than the demand would be if members of college sports teams were treated as professionals.

A further potential justification for restraining competition for inputs in college sports is that this policy is said to enhance competitive balance and therefore may raise the value of the entertainment. In addition, as Frank (2004) suggests, to the extent that college sports fans care about their teams’ relative performance, NCAA rules restricting competition for inputs may lead to reduced costs without sacrificing much output. For example, the NCAA limits the total number of football scholarships at Division I-A schools to 85, a reduction from its pre-1992 limit of $95 .{ }^{6}$ While such a decision may have marginally reduced the absolute quality of football entertainment, it likely had little effect on fans' enjoyment of a Bowl victory. In addition, it is possible that limits on roster size enhance competitive balance, providing another potential efficiency rationale for such restrictions. The potential effects on fan demand of amateurism and competitive balance distinguish analyses of sports from those of other industries, where presumably consumers care most about the absolute quality of output and not the status of the workers producing it or the relative status of the firms in the industry.

\footnotetext{
${ }^{5}$ For college athletes who make it to the NFL or NBA, lifetime permanent income may well be very high. Thus the exercise of monopsony power over these athletes while they are in college may not on net lead to a regressive transfer of wealth. But it is very rare for college athletes to make it to the professional ranks: according to Zimbalist (1999, p. 31), only 1.3\% of NCAA football players and 1.7\% of NCAA basketball players make it to the pros.

${ }^{6}$ See Sutter and Winkler (2003) and http://www.ncaa.org, accessed 6/16/06.
} 
In addition to suggesting that NCAA rules requiring amateurism may create value, McKenzie and Sullivan (1987) argue that with so many members, the NCAA can't possibly prevent a competitive market in players from arising. The authors suggest that in addition to receiving scholarships, athletes receive training and exposure, and McKenzie and Sullivan (1987) assert that the value of this package equals the players' marginal revenue products, implying that there are no monopsony rents. Moreover, the authors take the fact that no rival organizations to the NCAA have formed as further evidence against the existence of cartel rents.

To evaluate these alternative views of the NCAA, I begin by reviewing evidence on output restrictions and explicit restrictions on input payments. First, before 1984, the NCAA restricted output by controlling its members' access to televised games. One of the major problems of cartels is preventing entry by competing firms or groups which are attracted by the rents the cartel has generated. Consistent with this reasoning, in 1977, a group of colleges and universities with major football programs formed the College Football Association (CFA) in order to influence the NCAA's stand on televised games. ${ }^{7}$ In 1981, the CFA was ready to negotiate a separate television contract with NBC; however, the NCAA threatened to expel any school that signed the contract, an action that would have eliminated the affected schools' rights to NCAA basketball tournament revenue. The ability to issue such threats enabled the NCAA to prevent the dissipation of football television rents. However, in response, with CFA financial backing, two of its member schools, the University of Oklahoma and the University of Georgia, sued the NCAA for antitrust violations and won a Supreme Court decision in 1984, which ended NCAA control of broadcasting rights.

Since 1984, an explosion of separate television contracts has occurred, partially illustrated by the conference-level football contracts mentioned in Table 2. Table 3 takes

\footnotetext{
7 This discussion of the CFA is based on Siegfried and Burba (2004), pp. 802-805.
} 
a detailed look at quantity and price of televised college football games before and after the 1984 Supreme Court decision. It shows a sharp increase in quantity and an even sharper fall in price between 1983 and 1985, suggesting that before the Supreme Court decision, the NCAA indeed was using its monopoly power to restrict output and raise price. Ironically, it also appears that in 1983, the NCAA was operating in the inelastic portion of its demand curve, since over the next two years, price fell by about $3 / 4$, while quantity only rose by $50 \%$. If this interpretation of the price and quantity changes is correct, then the NCAA wasn't even fully exploiting its monopoly power before 1984, perhaps fearing litigation or attempts by some schools to negotiate separately with television networks. ${ }^{8}$ A further instance of output restriction, although not the subject of any lawsuit, was the NCAA's decision to reduce the number of bowl games from 50 during the 1940s to only nine by 1952; and in 1955, the NCAA restricted the number of practices and games for both football and basketball (Fleisher, Goff and Tollison 1992, p. $55)$.

Second, in addition to restricting output, the NCAA was found in 1995 by a Federal District Court to have illegally colluded to hold down the salaries of assistant coaches, a decision upheld on appeal. ${ }^{9}$ In 1991, the NCAA set a maximum compensation level for certain assistant coaches. These were designated Restricted Earnings Coaches, and their earnings were capped at \$12,000 during the academic year and \$4,000 for any summer camp earnings.

Several antitrust suits were filed against the NCAA on behalf of the assistant coaches, and they were consolidated into one class action. In 1995, a Federal Court decided for the plaintiffs, and damages to the coaches were ruled in 1998 to be $\$ 22.3$

\footnotetext{
${ }^{8}$ Of course, if the demand curve were shifting to the left during the 1980s, perhaps due to the expansion of television coverage of other sports on cable TV stations such as ESPN, then it is possible that the NCAA had been operating on the elastic portion of its demand curve before 1984. This scenario raises the possibility that a leftward demand shift explains the fall in price seen in Table 3. However, the fall in price was very sudden and dramatic, and it occurred immediately after the Supreme Court decision, lending plausibility to the monopoly power argument.

9 This discussion of the NCAA and assistant coaches' salary rules is based on Hamilton (2003).
} 
million. Under antitrust law, these were tripled to \$67 million. The NCAA appealed, but the $10^{\text {th }}$ Circuit Court of Appeals upheld the decision. The parties eventually settled for \$55.5 million, to be divided among roughly 1000 assistant coaches.

While courts have ruled that restricting television broadcasts and assistant coaches’ earnings were antitrust violations, the Supreme Court in the 1984 decision on television rights held that NCAA restraints on player mobility across schools and player compensation were essential for the production of competitive games (McKenzie and Sullivan, 1987, pp. 390-392). ${ }^{10}$ To evaluate this efficiency argument in favor of NCAA rules on player pay and mobility, I note that in professional sports, the logic of the Coase Theorem implies that restraints on player pay do not affect competitive balance as long as teams can trade player contracts efficiently. And most research on professional sports finds little effect of player free agency (which led to much higher salaries in baseball) on competitive balance, supporting this reasoning (Kahn 2000).

In the NCAA, limits on player compensation need not affect competitive balance, as long as schools can recruit players through other means such as having a highly qualified coaching staff or lavish facilities and academic support. The same reasoning applies to limits on roster size, and research on the impact on competitive balance of reducing the number of football scholarships from 95 to 85 is indeed inconclusive (Sutter and Winkler 2003). However, NCAA limits on player mobility could affect competitive balance. Specifically, before transferring to another school, a player must sit out a year (Fort, forthcoming, p. 495). This implies that if a low revenue school recruits a player who turns out to be better than expected, the mobility barrier caused by this rule might prevent movement to a school where one’s marginal revenue product would be higher.

\footnotetext{
10 NCAA limits on compensation were as of 2006 under attack as two class action antitrust lawsuits were filed in 2004 and 2006 challenging the NCAA's limits on the number of scholarships per football team and on the limit on the stipend per athlete in the big time football and men's basketball programs. See Farrey (2006) and Johnson (2006).
} 
There is likely to be an optimal level of competitive balance (which maximizes total revenue), and limits on mobility may be a way to achieve this.

If in fact the NCAA is using its power to reduce the earnings of athletes below competitive levels, then we should expect to see that players’ marginal revenue products are greater than their compensation. In sports, unlike other industries, it is possible to produce plausible estimates of individual workers’ marginal revenue products, and a series of papers does this for college athletes (Brown and Jewell 2004 and 2006; Brown 1993 and 1994). The basic methodology in these studies is to estimate cross-section models like the following:

1) Revenue $_{i}=a_{0}+a_{1}$ Draftees $_{i}+b^{\prime} X_{i}+e_{i}$,

where for school i, Revenue is total revenue (media plus ticket sales) from, for example, men's college basketball, Draftees is the number of players on the college team who were eventually drafted by the major professional league, in this case the NBA, X is a vector of control variables affecting revenue, such as market size, type of conference, and the impact of other inputs as proxied by past team success, and e is a disturbance term.

Recent analyses of the marginal revenue product (MRP) based on equations like (1) have been performed for college football, as well as men's and women's college basketball. In constant 2005 dollars, estimates of the MRP of a draft-quality player range from about $\$ 263,000$ for women’s basketball (based on the $2000-1$ season), to $\$ 495,000$ for college football (based on the 1995 season) and \$1.422 million for men’s college basketball (based on the 1995-6 season). ${ }^{11}$

\footnotetext{
11 The estimates for the two men's sports come from Brown and Jewell (2004, p. 159), and the figure for women's basketball is taken from Brown and Jewell (2006, p.98). It should be noted that some of these estimates attempt to take account of the endogeneity of recruiting high quality players, although the identification problem here is challenging. To produce constant dollar estimates, I use the PCE deflator. I inflate from the year during which a regular season ends (e.g., 1995 for the 1995 football season and 2001 for 2000-1 basketball season).
} 
These estimates of MRP can be compared to college athletes' compensation in order to study the issue of monopsonistic exploitation. According to NCAA rules, athletes are limited to receiving a scholarship and stipend, supplemented by up to $\$ 2,000$ of earnings from a job during the school year (Zimbalist 1999, p. 26). Since the cost of tuition, fees, room, board and incidentals comes to roughly $\$ 40,000$ at private schools, it appears that compensation is far below MRP for these revenue-producing athletes. Computations such as this are taken by some as evidence that the NCAA does indeed use its cartel power to exploit top athletes (Fleisher, Goff and Tollison 1992; Zimbalist 1999). However, as we have seen, McKenzie and Sullivan (1987) argue that in addition to the direct compensation represented by a scholarship and stipend, college athletes receive training and exposure that enhance their future earning power. If the value of this indirect compensation is high enough, then it is possible that total compensation to players does indeed equal their MRP, and thus the NCAA may not have or exercise cartel power over the athletes.

While coaching and exposure surely are part of a big time college athlete’s indirect compensation, the widespread incidence of under the table payments for top college athletes suggests that total allowable direct compensation plus the value of training and exposure are less than these players’ MRPs. For example, Sack (1991) surveyed 3500 current and retired NFL players in 1989, of whom 1182 responded. He found that $31 \%$ of them received under the table payments while in college and $48 \%$ claimed they knew of others who received them.

If these players were telling the truth, then it does appear that the market for college players shows a shortage at allowable compensation, suggesting that the NCAA indeed is attempting to use its cartel power. However, McKenzie and Sullivan (1987) argue that this interpretation is incorrect. Instead, these authors see such illegal payments as cheating on product quality, in the same way that an individual franchisee of a restaurant chain may be tempted to cheat. In this case, the product is amateur sport, and 
paying the athletes reduces the quality of the product. But, under this interpretation, one must ask why a school would pay money for an outcome that leads to a worse product; at least a cheating franchisee presumably saves money by cheating on, for example, product standards.

In my opinion, a more plausible interpretation of the use of under the table payments is that schools (or their boosters) are willing to pay to enhance product quality by bringing in and keeping top recruits. It is of course possible that perceptions that college players are collecting large amounts of money would reduce fan interest in these sports, but there is no evidence on this question. It may be individually rational for a school to violate NCAA rules and make under the table payments to attract star athletes. But such competition may be wasteful from society's point of view, since there will be a winning team regardless of recruiting efforts, and the resources devoted to players could have been spent on other university activities (Frank 2004). This is an additional efficiency argument for limiting competition for inputs. However, a school that pays a top athlete money to play may very well be raising absolute product quality by deterring the player from turning pro: there is indeed evidence that professional opportunities negatively influence college athletes’ propensity to stay in school (DeBrock, Hendricks and Koenker 1996). Moreover, a school that induces a player to remain in college rather than turn pro may indirectly raise the income of other schools, possibly countering the negative effect of reducing its competitors' winning percentages. This is the case since there is evidence from professional sports that top athletes such as Michael Jordan raise the revenue of competing teams in addition to of course their own team (Hausman and Leonard 1997). NCAA rules may well have lowered the quality of college basketball (i.e. if the loss of high quality players to the NBA outweighs the gain to fans due to the hypothesized entertainment value of amateurism).

The foregoing discussion implies that the efficiency effects of NCAA rules depend partly on the relative strength of fans’ demand for relative vs. absolute playing 
quality and the shape of players' supply curves to college sports teams. As long as there is some demand for relative quality, then unbridled competition will lead to a demand for inputs that is too large. On the other hand, if fans also care about absolute quality and if players' supply curves are sufficiently elastic, then the monopsony solution of lowered compensation may lead to an insufficiently low level of playing quality.

To be effective, a labor monopsonist depends on a relatively inelastic supply of the labor in question. And of course if players' supply curves are perfectly inelastic, then there would be no efficiency loss in restricting their pay. If playing college sports were most players' best alternative use of time by a large margin, then these conditions would seem to approximately hold. But as suggested above, potential college basketball players may seek other employments, in effect making their labor supply curves more elastic than otherwise. For example, as of the 2001-2 season, of the 366 American players in the NBA, fully 115 of them (31\%) entered the NBA before their college classes would have graduated, and 14 of these never went to college at all. ${ }^{12}$ These figures suggest that many top college or high school players may be at the margin between playing in college and trying to enter the NBA, whereas in previous times it was rare for players to enter the NBA early. If the supply of top players does continue to become more elastic, the NCAA may find it surplus-maximizing to allow higher levels of compensation for athletes, as ordinary monopsony models would predict. This reasoning could explain why the NCAA now allows athletes to earn money in a job on campus (see above), although the $\$ 2,000$ limit on such earnings may be too small to noticeably affect the supply of athletes.

Potentially counteracting these trends on early entry, the NBA and its union have recently (2005) limited players' ability to enter the league early by setting a minimum age of 19 and a minimum of one year past the graduation of one's high school class before

12 These figures are based on data collected for analysis in Kahn and Shah (2005). 
one is allowed to enter. ${ }^{13}$ In addition, in 2004, a college sophomore unsuccessfully challenged under the anti-trust laws the NFL’s rule preventing players from entering before three years after high school graduation. ${ }^{14}$ Both the NBA's new rule and the NFL's rule on underclassmen make the supply of athletes to colleges less elastic and thus increase the potential for rent extraction.

The monopsonistic exploitation of revenue-producing college athletes is not racially neutral. The participants in the major revenue-producing sports of men's basketball and football are disproportionately African-American. For example, in the 1990s, while black students comprised only about 7\% of undergraduates at Division I schools, $46 \%$ of football players and $60 \%$ of basketball players at these schools were black (Sack and Staurowsky 1998, p. 105). One can view this imbalance in either of two ways. On the one hand, minority athletes are receiving a scholarship and an opportunity to go to college that might not have been there in the absence of college sports. On the other hand, given our results on monopsonistic exploitation, it is clear that these athletes are bearing the costs of allowing the NCAA to collude over athlete pay, at least assuming that college sports would retain their popularity even if the players were paid market salaries.

It is likely that coaches are one constituency that benefits from the limits on player pay, and participants in non-revenue sports also benefit (see below). Minority representation in these groups is much lower than it is among revenue-producing athletes. For example, a recent study of college football coaches over the 1990-2000 period found that only 3.8\% were black (Mixon and Treviño 2004, p. 650). And among Division I

\footnotetext{
${ }^{13}$ See the 2005 collective bargaining agreement between the NBA and the NBA Players Association, available at: http://www.nbpa.com/cba_articles.php, accessed March 24, 2006.

14 The player, Maurice Clarett, initially prevailed at the District Court level, but this decision was overturned by the Second Circuit of Appeals, and the US Supreme Court refused to intervene. These decisions are available at: http://www.supremecourtus.gov/docket/03a870.htm , http://files.findlaw.com/news.findlaw.com/wp/docs/nfl/clarettnfl20504opn.pdf , and http://files.findlaw.com/news.findlaw.com/usatoday/docs/nfl/clarettnfl52404opn.pdf , accessed March 24, 2006.
} 
schools in the 2003-4 academic year, $58.2 \%$ of male basketball players and $44.3 \%$ of football players were "Black, Non-Hispanic"; in contrast, Black, Non-Hispanic representation in all male sports was only 24.6\% (NCAA 2005, p. 29).

If we accept that the use of under the table payments is evidence that the NCAA's rules potentially produce cartel rents, is there any other evidence of such potential rents? Put differently, is there any evidence of the kind of rent dissipation that is said to occur in other cartels that cannot completely control member behavior? For example, there are no limits on head coaches' salaries or the quality of athletic facilities and dorms. It is likely that NCAA rules on player compensation raise the MRP of effective coaches and the value of top quality facilities, since these become the primary means of attracting athletes. In contrast, a professional sports team can always bid for players. While there is no research assessing the portion of college coaches' income that is due to their ability as recruiters, this analysis hypothesizes that their incomes would fall if the market for players were made competitive. Moreover, Fleisher, Goff and Tollison (1992, pp. 85 and 91) document high levels of coaches' incomes as well as the construction of lavish training facilities that the authors interpret as rent dissipation. Presumably, these substitute to some degree for direct payments to athletes as recruiting devices.

An additional indicator of the existence of cartel rents is activity pursued by cartel members to protect these rents. The NCAA has faced rival organizations but in some cases has been able to keep its monopoly position over college sports. ${ }^{15}$ First, the Association of Intercollegiate Athletics for Women (AIAW) was a federation founded in 1971 to advance and make rules for women’s collegiate athletics in much the same way that the NCAA did for men’s sports. In the early 1980s, the NCAA began scheduling women's championships and offered inducements such as including the women's basketball championship tournament in its television package; it also scheduled the finals

15 This discussion of rivals to the NCAA is based on Zimbalist (1999, pp. 57-58 and p. 112) and Katz (2005). 
to take place at the same time as the AIAW's finals. By 1982, the AIAW was gone. Second, the National Invitation Tournament (NIT) was a rival men's college basketball tournament that at one time was more prestigious than the NCAA tournament. But in 1960 the NCAA implemented a rule requiring members to give the NCAA tournament priority, eventually relegating the NIT to second class status. Perhaps not surprisingly, a group of schools closely associated with the NIT (the Metropolitan Intercollegiate Basketball Association — the MIBA, made up of Fordham, Manhattan, St. Johns, Wagner, and New York University) filed an antitrust suit over the NCAA's rule, which was settled in 2005 after four years of litigation. In the settlement, the NCAA bought the rights to the NIT for \$40.5 million and compensated the MIBA an additional \$16 million in return for dropping the suit (Katz 2005).

Third, the creation of the Division I-A, etc., system and the Bowl Championship Series have been interpreted as a way for the big time athletic powers to protect the rents they receive (Leeds and von Allmen 2005). In order to be a member of the Division I group, a school must offer minimum numbers of men's and women's sports, as well as offer scholarships with a specific minimum and maximum; and in order to be a Division I-A football school, one must additionally satisfy minimum football fan attendance standards. ${ }^{16}$ In addition to these explicit membership hurdles, some have interpreted the tightening of academic standards in the NCAA (with respect to SAT scores and high school grades and courses) as an attempt by some schools to protect their cartel position (Fleisher, Goff and Tollison 1992).

Potentially counteracting these trends toward erecting entry barriers into the elite groups of big time programs is the recent proliferation of conference realignments and enlargements. For example, the Pac 8 has become the Pac 10; the Big 10 has added an $11^{\text {th }}$ team; the Big 8 has become the Big 12; the Atlantic Coast Conference grew from

\footnotetext{
${ }^{16}$ For further details on these membership requirements, see the Appendix.
} 
eight schools in 1978 to 12 today; the Big East grew from seven members in 1979 to its current membership of 16; and athletic powers Boston College, Virginia Tech and the University of Miami have all recently left the Big East for the Atlantic Coast Conference. ${ }^{17}$ In addition, many conferences such as the Big 10 have added post-season conference basketball tournaments that take place before the NCAA championships. These conference tournaments can be seen as a partial consequence of the 1984 Supreme Court decision discussed earlier in which the NCAA was no longer allowed to control access to televised games. These tournaments may partially represent the kind of entry discussed by McKenzie and Sullivan (1987) in which the monopoly rents of a presumed NCAA cartel are reduced. That is, the growth of these conference tournaments likely adds to the supply of games and may dilute some of the monopoly power the NCAA tournament enjoys.

The enlargement of conferences may be seen as an attempt to counteract this competition by reducing the potential supply of competing conference tournaments. But the threats of schools to leave conferences and offers by some conferences to big name schools all put the NCAA's rent protection strategies at risk. For example, the University of Miami, a traditional athletic power was induced to join the Big East in 1990 and move to the Atlantic Coast Conference in 2003 (Fort, forthcoming, p. 489). While this movement has all taken place within the NCAA, the side payments needed to attract major programs to change conferences likely reflect the dissipation of some rents. For example, in 2003, the Big East guaranteed Miami \$45 million over five years if it stayed in the conference rather than move. In addition, the Big East sued the ACC over this move, and the parties eventually settled by scheduling additional football games between the two conferences. ${ }^{18}$ Thus, the mobility threat which was exercised resulted in the

${ }^{17}$ See Fort (forthcoming), pp 487-8, the Big East web site: http://www.bigeast.org/school-bio/bige-schoolbio.html , accessed March 23, 2006, and the Atlantic Coast Conference web site: http://theacc.collegesports.com/this-is/acc-this-is.html , accessed March 23, 2006.

${ }_{18}$ See http://espn.go.com/ncaa/news/2003/0630/1574726.html and http://sports.espn.go.com/ncaa/news/story?id=2052787, both accessed March 29, 2006. 
expansion of output of high quality games, at least as far as the Big East goes. If interconference mobility were outlawed, conferences could better capture the income produced at home and on the road by successful programs.

\section{Rent Dissipation or Rent Sharing? The Financial Effects of College Sports on the Rest of the University}

If the NCAA is an effective cartel, what happens to the rents it generates? Are they fully dissipated in coaches' salaries, facilities, etc.? Are some of them shared with the rest of the university? Does intercollegiate athletics indirectly generate financial benefits for universities through alumni contributions, state appropriations or attraction of better students? A reasonable first step in analyzing the impact of college sports on the rest of the university is to ask whether on average the revenue-producing sports earn a profit and, if so, whether there are direct transfers to the university generally.

Table 4 shows financial results for the Divisions of the NCAA for 2003, and it indicates for each Division that the direction of transfers on net is from the university to athletic departments, on average. For example, for Division IA athletic programs, which are the most lucrative, Table 4 shows that the average athletic department took in $\$ 29.4$ million in revenue in 2003 and had \$27.2 million in expenses; however, included in this revenue figure is $\$ 2.8$ million of transfers from the university to the athletic budget (“institutional support”). Thus, before accounting for institutional support, the average Division I-A program lost $\$ 600,000$. The other Divisions also each lost money, with losses averaging \$3.5-\$3.7 million per school in Divisions I-AA and I-AAA; \$1.3-\$1.6 million per Division II member, and \$279,000 to \$742,000 per institution in Division III.

Table 5 suggests that Table 4's figures indicating average losses for 2003 were fairly typical. It shows that, between 1993 and 2003, the average profit in constant (2005) dollars for each of the Division I and II categories was negative in each case 
except for 1999, during which the Division I-A schools broke even. ${ }^{19}$ Schools in Divisions I-AA, I-AAA, or Division II with football lost over \$1 million on average in each year, while Division II schools without football lost at least $\$ 634,000$ each year. Division I-A has shown the best profit results, with losses ranging from 0 to $\$ 936,000$. Some of the expenses shown in Table 4 went to support nonrevenue sports: according to Fulks (2005a, p. 30), in 2003, for Division I-A programs, men’s sports made roughly an average \$6.1 million profit per school, while women’s sports lost about \$3.6 million, including institutional support (there were also \$300,000 of losses on non-gender specific athletic items). Football and men's basketball were by far the most lucrative sports, raising \$12.97 million and \$4.25 million in revenue per Division I-A school in 2003, respectively, or about 59\% of total revenues, including institutional support (Fulks 2005a, pp. 30 and 48). Moreover, these two sports together generated an average of \$7.95 million profit per school in 2003. The only other men’s or women’s sport to show an average positive profit was men’s ice hockey, which had a profit of \$353,000 per school.

An increasing claim on the revenues generated by big time sports is caused by the enforcement of Title IX of the Educational Amendments of 1972, which outlaws gender discrimination in educational institutions. Since the passage of Title IX, Federal agencies have periodically issued guidelines for its enforcement. The most influential of these is the Department of Health, Education and Welfare's 1979 guidelines suggesting a threepart test in which a school can demonstrate compliance with Title IX. Specifically, an institution can show compliance if:

“1) the male/female ratio of athletes at an institution is 'substantially proportionate' to the male/female ratio of undergraduate enrollment, 2) it has a 'history and continuing practice of program expansion' for women, or 3) it is 'fully and effectively' accommodating the interests and abilities of women” (Secretary of Education's Commission on Opportunity in Athletics, 2003, p. 15).

${ }^{19}$ Data for past years for the Division III schools were not reported in Fulks (2005b). 
Most of the attention and controversy around gender equity in athletics has concerned the proportionality test. Although the guidelines clearly don't require proportionality, of the three options for showing compliance, it is the most objective. Thus, schools may focus on the proportionality test as the safest way of immunizing themselves against litigation. Of course, the proportionality test does not require proportional expenditures. But it could lead schools to reallocate their athletic budgets in ways that dissipate some of the rents they would otherwise have generated.

Critics of Title IX have focused on the proportionality test as essentially requiring a quota, which could lead to inefficiencies in allocating athletic slots between men and women (Epstein 2002). For example, schools may cut men's sports and thus threaten the fund-raising function among alumni (see below). The test assumes that men and women have the same level of interest in playing sports, which may or may not be true. On the other hand, advocates of Title IX's proportionality test believe that its enforcement will encourage women to participate in sports. ${ }^{20}$ If schools out of compliance are in fact discriminating against women, the current allocation of slots may in fact be suboptimal in the same way that a labor market with discrimination is economically inefficient.

In studying the effects of Title IX on athletic department resource allocation, Carroll and Humphreys (2000) examined data from Division I institutions over the 199095 period; the authors found that 35\% of schools decreased the number of men's sports, while only $18 \%$ added men's sports offerings; in contrast, $83 \%$ added women’s sports,

\footnotetext{
20 See Stevenson (2005) for evidence that Title IX has increased participation by girls in high school sports, a development that raises the stock of college women interested in athletics. In addition, there is evidence from colleges suggesting that Title IX has increased women's participation rates in athletics. For example, from 1966-7 to 1971-2, a period which just preceded the passage of Title IX, women as a share of intercollegiate athletes at degree-granting higher education institutions rose from $9.1 \%$ to $15.0 \%$; their proportion of the student body went from $39.7 \%$ to $41.8 \%$. In contrast, in the ten years following the passage of Title IX, women's representation rose sharply both in the student body (51.7\%) and among athletes (30.4\%). These figures suggest that Title IX caused already increasing levels of women's enrollment and athletic participation to rise even faster. These data are taken from the Secretary of Education’s Commission on Opportunity in Athletics (2003, p.13), and NCES (2003, p. 210).
} 
and only 5\% reduced them (Carroll and Humphreys 2000, p. 361). ${ }^{21}$ Thus, it appears that women's sports are substituting at the margin for men's sports, an effect that may be due in part to Title IX, although it could also have been caused by exogenous increases the demand by women to play college sports.

The data in Tables 4 and 5 showing net transfers from the university to the athletic department suggest that if university activities outside varsity sports reap major financial or other benefits from their revenue producing sports, the benefits must be indirect. There is evidence on two types of indirect benefits: financial such as donations or state appropriations and reputational, as judged by the quantity and quality of student applications. A large number of econometric studies have investigated the effects of sports success on donations, with mixed results. Findings are sensitive to the inclusion of university fixed effects, the definition of athletic success (e.g. spending, winning percentages, bowl appearances, NCAA tournament appearances), the sample (public vs. private universities, for example), and the type of giving (i.e., restricted vs. unrestricted donations). ${ }^{22}$ Two recent studies use the statistically more appropriate fixed effects methods on comprehensive samples to estimate the impact of college sports on alumni giving. First, Litan, Orszag and Orszag (2003) find that during the 1993-2001 period, football winning percentage at Division I-A schools was insignificantly negatively associated with alumni giving, with coefficients ranging in magnitude from $\mathbf{\$ 2 9 , 0 0 0}$ to -\$4.5 million. Second, Humphreys and Mondello (forthcoming) study a comprehensive panel of Division I schools over the 1976-1996 period and find significantly positive effects on restricted donations to public institutions of bowl appearances (\$1.17 million extra for appearing) and NCAA men’s basketball tournament appearances ( $\$ 825,000$ for appearing). For private institutions, only basketball appearances had a significant effect

\footnotetext{
${ }^{21}$ Despite such apparent attempts to comply with the proportionality standard, as of the 2001-2 academic year, on average schools were still out of compliance by roughly 13 percentage points (i.e. female representation in sports was 13 percentage points behind female representation in the student body). See Anderson, Cheslock and Ehrenberg (forthcoming).

${ }^{22}$ For reviews, see Frank (2004), Humphreys and Mondello (forthcoming), or Goff (2004).
} 
on restricted donations $(\$ 960,000)$, while bowl appearances had an insignificant coefficient of $-\$ 1.2$ million. ${ }^{23}$ One interpretation of these two studies is that bowl appearances or NCAA tournament appearances are a better indicator of athletic success than winning percentage. Finally, some case studies of individual universities also found that athletic success raised donations (Goff 2004).

It is sometimes argued that athletic success for public universities makes state legislatures more favorable to them. Indeed, a recent study of 570 public universities from 1976-96 used fixed effects methods to find that fielding a Division I football team raised state appropriations the next year by about $\$ 2.6$ million in 1982 dollars using the Higher Education Price Index (HEPI) deflator, or about $8 \%$ of the average appropriation (Humphreys forthcoming). In 2003 dollars (using the HEPI), this comes to about $\$ 6.2$ million, or about 23\% of the average revenue of Division I-A athletic programs. ${ }^{24}$

Athletic success can affect the quality and quantity of students who want to go to a particular school. A number of studies of this issue based on data through the early 1990s found mixed results, with some authors showing that athletic success raised future students' SAT scores and others finding little effect (Goff 2004). However, two studies from the 1990s find that fielding a Division I football team (Sandy and Sloane 2004) or making Bowl appearances (Tucker 2005) raise future students' SATs: these effects were a relatively modest 12-13 point SAT increase associated with moving from Division IAA to I-A or going to an additional bowl game in the last five years. In addition, changing to a Division I-A level football team raised the size of the university by about 2000 students, presumably through student applications (Sandy and Sloane 2004).

\footnotetext{
${ }^{23}$ It should be noted that Humphreys and Mondello's (forthcoming) significantly positive findings applied only to restricted donations, since the authors found no significant effects of athletic success on unrestricted donations. While restricted contributions are likely earmarked by the donor for athletic programs, these funds may reduce the demand for institutional support, increasing the level of resources available for the rest of the university.

${ }^{24}$ HEPI data are take from http://www.inform.umd.edu/CampusInfo/Departments/BFA/inflation2.html , accessed February 21, 2006.
} 
These positive findings for the impact of athletic success should be tempered by the realization that none of the authors attempts to control for the endogeneity of athletic expenditures, a problem that school fixed effects or state fixed effects models might not solve. Schools may be “on their way up” in general for other reasons, such as newlyappreciated locational advantages or large unanticipated changes in endowments, and these may lead to future success on many fronts, including attracting a good student body, building good teams, and generating further high levels of financial support. Nonetheless, the findings are suggestive of some positive indirect effects of individual schools’ athletic success.

\section{Conclusions}

This paper has presented research on the impact of college sports on a variety of outcomes. Big time sports programs appear to extract rents from revenue-producing athletes and spend them on facilities, coaches' salaries and nonrevenue sports; on average, college sports drain revenue from the rest of the university. However, there is some evidence of positive indirect effects on public and private contributions; and for the bulk of schools, sports success appears to generate interest by a larger group of students than would otherwise be the case, allowing universities to expand and have a modestly stronger student body at the same time. In this consumer-oriented era even selective universities need to maintain their appeal to future applicants, many of whom are future alumni or future voters for state legislatures, and having successful sports programs may be a way to do this. 


\section{Appendix: Membership Criteria for NCAA Divisions}

As mentioned in the text, the NCAA has created Divisions with differing membership rules. This explanation of the Division system is based on Fulks (2005a, p. 133). In each Division, each sport must have a minimum roster size and schedule a minimum number of games. Division I schools must have at least seven men's and seven women's sports, or six men's and eight women's. All Division I schools must schedule at least a minimum number of games against other Division I schools and must abide by financial award minima and maxima with respect to the number of awards. Division I schools with football are classified as I-A or I-AA. For membership in Division I-A , a school must have a football team which satisfies attendance criteria. Division I schools without football programs are classified I-AAA.

Division II schools must have at least four men's and four women's sports, and at least two of these must be team sports for each gender. There are opponent scheduling criteria for football and men's and women's basketball. There are maximum numbers of financial awards for each sport.

Division III schools must have at least five men's and five women's sports, again with at least two team sports for each gender. These schools are not allowed to award athletic scholarships. 


\section{References}

Anderson, Deborah J., John J. Cheslock, and Ronald G. Ehrenberg. Forthcoming. "Gender Equity in Intercollegiate Athletics: Determinants of Title IX Compliance.” Journal of Higher Education.

Bowen, William G. and Sarah A. Levin. 2003. Reclaiming the Game. Princeton: Princeton University Press.

Brown, Robert W. 1993. "An Estimate of the Rent Generated by a Premium College Football Player.” Economic Inquiry. 31:4 (October), pp. 671-684.

Brown, Robert W. 1994. "Measuring Cartel Rents in the College Basketball Player Recruitment Market.” Applied Economics. 26:1(January), pp. 27-34.

Brown, Robert W. and R. Todd Jewell. 2004. "Measuring Marginal Revenue Product in College Athletics: Updated Estimates.” In John Fizel and Rodney Fort, eds., Economics of College Sports. Westport, CT.: Praeger, 2004, pp. 153-162.

Brown, Robert W. and R. Todd Jewell. 2006. "The Marginal Revenue Product of a Women’s College Basketball Player.” Industrial Relations. 45:1 (January), pp. 96-101.

Carroll, Kathleen A. and Brad R. Humphreys. 2000. "Nonprofit Decision Making and Social Regulation: The Intended and Unintended Consequences of Title IX." Journal of Economic Behavior \& Organization. 43:3 (November), pp. 359-376.

DeBrock, Lawrence, Wallace Hendricks, and Roger Koenker. 1996. “The Economics of Persistence: Graduation Rates of Athletes as Labor Market Choice.” Journal of Human Resources. 31:3 (Summer), pp. 513-539.

Epstein, Richard A. 2002. "Law and Economics: Just Scrap Title IX.” National Law Journal (October), on-line journal: http://www.law.uchicago.edu/news/epsteinIX.html, accessed February 2, 2006.

Farrey, Tom. 2006. “NCAA Might Face Damages in Hundreds of Millions.” ESPN The Magazine, February 21: http://sports.espn.go.com/ncaa/news/story?id=2337810, accessed April 6, 2006.

Fleisher III, Arthur A., Brian L. Goff and Robert D. Tollison. 1992. The National Collegiate Athletic Association: A Study in Cartel Behavior. Chicago: University of Chicago Press.

Fort, Rodney. Forthcoming. Sports Economics, $2^{\text {nd }}$ Edition. Upper Saddle River, NJ: Prentice Hall.

Frank, Robert H. 2004. Challenging the Myth: A Review of the Links Among College Athletic Success, Student Quality, and Donations. Knight Foundation

Commission on Intercollegiate Athetics Report, May. 
Fulks, Daniel L. 2005a. 2002-03 NCAA Revenues and Expenses of Divisions I and II Intercollegiate Athletics Programs Report. Indianapolis: National Collegiate Athletic Association (February).

Fulks, Daniel L. 2005b. 2002-03 NCAA Revenues and Expenses of Division III Intercollegiate Athletics Programs Report. Indianapolis: National Collegiate Athletic Association (May).

Goff, Brian. 2004. "Effects of University Athletics on the University: A Review and Extension of Empirical Assessment.” In John Fizel and Rodney Fort, eds., Economics of College Sports. Westport, CT.: Praeger, 2004, pp. 65-85.

Hamilton, Bruce W. 2003. "Class Action in Price-Fixing Litigation When the Fixed Price is a Wage Rate: Law et al. v. NCAA.” Antitrust Bulletin. 48:2 (Summer), pp. 505-529.

Hausman, Jerry A. and Gregory K. Leonard. 1997. "Superstars in the National Basketball Association: Economic Value and Policy.” Journal of Labor Economics. 15:4 (October), pp. 586-624.

Humphreys, Brad. R. Forthcoming. "The Relationship Between Big-Time College Football and State Appropriations to Higher Education.” International Journal of Sports Finance.

Humphreys, Brad R. and Michael Mondello. Forthcoming. "Intercollegiate Athletic Success and Donations at NCAA Division I Institutions.” Journal of Sports Management.

Johnson, Greg. 2006. “This Goes Against Regulations.” Los Angeles Times, March 28: http://www.latimes.com/sports/la-sp-antitrust28mar28,0,5874123.story?coll=laheadlines-sports , accessed April 6, 2006.

Kahn, Lawrence M. 2000. “The Sports Business as a Labor Market Laboratory.” Journal of Economic Perspectives. 14:3 (Summer), pp. 75-94.

Kahn, Lawrence M. and Malav Shah. 2005. "Race, Compensation and Contract Length in the NBA: 2001-2.” Industrial Relations. 44:3 (July), pp. 444-462.

Katz, Andy. 2005. “NCAA Buys Tournaments, Ends NIT Litigation.” ESPN news story: http://sports.espn.go.com/ncb/news/story?id=2136724, accessed February $16,2006$.

Leeds, Michael and Peter von Allmen. 2005. The Economics of Sports, $2^{\text {nd }}$ Edition. Boston: Pearson Addison Wesley.

Litan, Robert E., Jonathan M. Orszag and Peter R. Orszag. 2003. The Empirical Effects of Collegiate Athletics: An Interim Report. Washington, DC: Sebago Associates. Commissioned by the National Collegiate Athletic Association, August.

McKenzie, Richard B. and E. Thomas Sullivan. 1987. "Does the NCAA Exploit College Athletes? An Economics and Legal Reinterpretation.” Antitrust Bulletin. 32:2 (Summer), pp. 373-399. 
Mixon Jr., Franklin G. and Len J. Treviño. 2004. “How Race Affects Dismissals of College Football Coaches.” Journal of Labor Research. 25:4 (Fall), pp. 645-656.

National Center for Education Statistics (NCES). 2003. "Digest of Education Statistics 2002.” Washington, DC: NCES, June.

National Collegiate Athletic Association (NCAA). 2005. 1999-00 - 2003-04 NCAA Student-Athlete Ethnicity Report. Indianapolis: NCAA, January.

Panaccio, Tim. 2005. “Comcast May Bid to Televise NHL.” Philadelphia Inquirer. July 19. Accessed on line: http://www.philly.com/mld/philly/sports/hockey/12164762.htm , February 15, 2006.

Sack, Allen L. 1991. “The Underground Economy of College Football.” Sociology of Sport Journal. 8:1 (March), pp. 1-15.

Sack, Allen L. and Ellen J. Staurowsky. 1998. College Athletes for Hire: The Evolution and Legacy of the NCAA's Amateur Myth. Westport, CT: Praeger.

Sandy, Robert and Peter Sloane. 2004. "Why Do U.S. Colleges Have Sports Programs?” In John Fizel and Rodney Fort, eds., Economics of College Sports. Westport, CT.: Praeger, 2004, pp. 87-109.

Secretary of Education's Commission on Opportunity in Athletics. 2003. “ 'Open to All’: Title IX at Thirty.” Report prepared for the Secretary of Education, February.

Siegfried, John J. and Molly Gardner Burba. 2004. “The College Football Association Television Broadcast Cartel.” Antitrust Bulletin. 49: 3 (Fall), pp. 799-819.

Stevenson, Betsey. 2005. "Beyond the Classroom: Using Title IX to Measure the Return to High School Sports.” Unpublished working paper, The Wharton School, University of Pennsylvania, July.

Sutter, Daniel and Stephen Winkler. 2003. "NCAA Scholarship Limits and Competitive Balance in College Football.” Journal of Sports Economics. 4:1 (February), pp. 3-18.

Tucker, Irvin B. 2005. “Big-Time Pigskin Success.” Journal of Sports Economics. 6:2 (May), pp. 222-229.

Zimbalist, Andrew. 1999. Unpaid Professionals. Princeton: Princeton University Press. 
Table 1: Total Ticket Revenue, 1999

Sport Revenue

Major League Baseball

$\$ 671$ million

NCAA Division I Football and Men's Basketball \$757 million

National Basketball Association

National Football League

$\$ 967$ million

National Hockey League

$\$ 730$ million

$\$ 731$ million

Source: Sandy and Sloane (2004), p. 88. 
Table 2: Average Annual Broadcast Revenues, Media Contracts in Force as of 2005

Sport

Revenue

NCAA Men's National Basketball

Tournament

NCAA Football: ACC, Big East, Big-

12,Notre Dame, Pac-10 Combined

Major League Baseball

National Basketball Association

National Football League

National Hockey League (2004)

\$564 million

$\$ 111$ million

$\$ 550$ million

$\$ 767$ million

$\$ 2.2$ billion

$\$ 120$ million

Sources: NCAA basketball and football--Fort (forthcoming);

Panaccio (2005). 
Table 3: College Football Television Revenue Before and After the 1984 Supreme Court Decision Ending NCAA Control of Television Broadcasts (2004 Dollars)

\begin{tabular}{cccc} 
Year & $\begin{array}{c}\text { Number of Games } \\
\text { Televised }\end{array}$ & $\begin{array}{c}\text { Total Revenue } \\
\text { (millions) }\end{array}$ & $\begin{array}{c}\text { Revenue Per Game } \\
\text { (millions) }\end{array}$ \\
\hline 1980 & 24 & $\$ 70.46$ & $\$ 2.94$ \\
1981 & 24 & $\$ 68.00$ & $\$ 2.83$ \\
1982 & 28 & $\$ 114.52$ & $\$ 4.09$ \\
1983 & 28 & $\$ 120.35$ & $\$ 4.30$ \\
1984 & 36 & $\$ 39.66$ & $\$ 1.10$ \\
1985 & 42 & $\$ 47.00$ & $\$ 1.12$ \\
1986 & 42 & $\$ 49.56$ & $\$ 1.18$ \\
1987 & 42 & $\$ 46.17$ & $\$ 1.10$ \\
1988 & 43 & $\$ 44.13$ & $\$ 1.03$ \\
\hline
\end{tabular}

Source: Fort (forthcoming), p. 485. 
Table 4: Financial Results, Intercollegiate Sports, 2003 (in thousands of dollars, on a per school basis)

\begin{tabular}{lcccccccc} 
Division & Total Revenue & $\begin{array}{c}\text { Revenue } \\
\text { Institutional } \\
\text { Support }\end{array}$ & $\begin{array}{c}\text { without } \\
\text { Institutional } \\
\text { Support }\end{array}$ & Expenses & Total Profit & $\begin{array}{c}\text { Total Profit } \\
\text { without } \\
\text { Institutional } \\
\text { Support }\end{array}$ & $\begin{array}{c}\text { No. of Schools } \\
\text { Athletes/school }\end{array}$ \\
\hline I-A & $\$ 29,400$ & $\$ 2,800$ & $\$ 26,600$ & $\$ 27,200$ & $\$ 2,200$ & $-\$ 600$ & 117 & 578 \\
I-AA & $\$ 7,200$ & $\$ 3,400$ & $\$ 3,800$ & $\$ 7,500$ & $-\$ 300$ & $-\$ 3,700$ & 124 & 487 \\
I-AAA & $\$ 6,200$ & $\$ 3,200$ & $\$ 3,000$ & $\$ 6,500$ & $-\$ 300$ & $-\$ 3,500$ & 86 & 304 \\
II with football & $\$ 2,600$ & $\$ 1,500$ & $\$ 1,100$ & $\$ 2,700$ & $-\$ 100$ & $-\$ 1,600$ & 151 & 357 \\
II without football & $\$ 1,700$ & $\$ 1,100$ & $\$ 600$ & $\$ 1,900$ & $-\$ 200$ & $-\$ 1,300$ & 131 & 186 \\
III with football & $\$ 2,509$ & $\$ 1,681$ & $\$ 828$ & $\$ 1,570$ & $\$ 939$ & $-\$ 742$ & 237 & 461 \\
III without football & $\$ 1,614$ & $\$ 993$ & $\$ 621$ & $\$ 900$ & $\$ 714$ & $-\$ 279$ & 188 & 244 \\
\hline
\end{tabular}

Sources: Fulks $(2005 a, b)$. Institutional support consists of transfers from the college or university to its athletic department. 
Table 5: Average Real Profit Per Institution, Not Including Institutional Support (thousands of 2005 dollars)

\begin{tabular}{lcccccc} 
Division & 1993 & 1995 & 1997 & 1999 & 2001 & 2003 \\
\hline I-A & $-\$ 254$ & $-\$ 243$ & $-\$ 936$ & $\$ 0$ & $-\$ 654$ & $-\$ 633$ \\
I-AA & $-\$ 1,775$ & $-\$ 2,066$ & $-\$ 2,340$ & $-\$ 2,510$ & $-\$ 3,707$ & $-\$ 3,903$ \\
I-AAA & $-\$ 1,395$ & $-\$ 1,702$ & $-\$ 2,106$ & $-\$ 2,852$ & $-\$ 3,053$ & $-\$ 3,692$ \\
II with football & $-\$ 1,014$ & $-\$ 1,094$ & $-\$ 1,053$ & $-\$ 1,369$ & $-\$ 1,417$ & $-\$ 1,688$ \\
II without football & $-\$ 634$ & $-\$ 729$ & $-\$ 936$ & $-\$ 1,027$ & $-\$ 1,199$ & $-\$ 1,371$ \\
\hline
\end{tabular}

Sources: Fulks (2005a, p. 23);

http://www.bea.gov/bea/dn/nipaweb/TableView.asp\#Mid, accessed April 3, 2006.

Personal consumption expenditures price deflator used to correct for inflation. 